\title{
Unødvendige innleggelser?
}

De fleste fastleger og legevaktleger vil oppleve å bli kontaktet av pårørende eller hjemmesykepleien med bestillinger om innleggelse fordi det «ikke går hjemme lenger». I slike situasjoner vil innleggelsen nesten alltid være basert på komparentopplysninger om sykdomsbilde og funksjonsendring, siden disse pasientene ofte vil ha kognitiv svikt. Denne type informasjon er ofte fragmentert og usystematisert. I svært mange kommuner er utvekslingen av informasjon mellom legene og personer fra pleie- og omsorgstjenestene lite strukturert og avhengig av enkeltpersoners initiativ (1). Det er derfor behov for å utvikle bedre modeller for samarbeid for å underlette kommunikasjonen og for å få en klarere felles forståelse av situasjonen. Dette gjelder spesielt pasienter hvor det har skjedd raske endringer i sykdomsbilde eller funksjonsnivå. Hos eldre skyldes dette ofte en bakenforliggende sykdom som kan behandles.

Lillebø og medarbeidere (2) har i dette nummer av Tidsskriftet en tankevekkende og innsiktsfull kasuistikk om en kvinne med slik bakenforliggende sykdom. Hun ble innlagt med delirium i medisinsk avdeling av «sosiale årsaker», det vil si i påvente av sykehjemsplass, fordi hun ikke kunne være hjemme lenger. «Sosiale årsaker» eller «akutt pleie» er begreper som det ikke er uvanlig å bruke om sykehusinnleggelser man antar er medisinsk unødvendige. Kanskje gjelder dette spesielt de eldste pasientene (3). Kasuistikken poengterer viktigheten av god anamnese og kliniske undersøkelser, men illustrerer også nødvendigheten av komparentopplysninger og god informasjonsutveksling mellom hjemmesykepleien og innleggende lege. Videre er den aktuell i debatten knyttet til samhandlingsreformen - hvilke pasienter skal innlegges i sykehus og er det slik at mange eldre innlegges unødig?

Alle kommuner skal i 2012, som en konsekvens av samhandlingsreformen, inngå avtaler med helseforetakene om hvilke oppgaver som er kommunenes ansvar og hvilke som er spesialisthelsetjenestens. I tillegg skal alle kommuner innen 2016 etablere akuttbehandlingsplasser til bruk både før, i stedet for og etter sykehusinnleggelser. En av hovedutfordringene er at det ikke foreligger noen studier som viser nytten av akuttbehandling for pasienter med uavklart medisinsk tilstand i kommunal institusjon i stedet for sykehusinnleggelse (4). Aaraas har vist at sykestuer i Finnmark kan fungere som et faglig adekvat alternativ til innleggelse ved forverring av en kronisk lidelse for pasienter med avklart medisinsk tilstand, for terminal behandling eller for etterbehandling (5). En pågående studie, der man skal analysere nytteeffekten av innleggelser ved Sjukestugu i Hallingdal i stedet for i sykehus, kan kanskje gi noen avklaringer. Det er ellers godt dokumentert at etterbehandling i helsehus (forsterket sykehjem) etter sykehusopphold kan gi færre reinnleggelser og lavere dødelighet (6).

En nyere rapport viser at såkalt unødvendige innleggelser av eldre kan være et marginalt problem (7). Det er viktig å ta hensyn til at symptomatologien ved akutt sykdom hos gamle ofte er ukarakteristisk. Pasientgruppen er kjennetegnet av multisykelighet, høyt legemiddelforbruk, kognitive problemer og utfordringer med å greie seg i dagliglivet. Ved akutt alvorlig sykdom kan de utvikle uspesifikke symptomer og tegn, preget av raskt innsettende svikt i evnen til å greie seg selv, slik som delirium («akutt forvirring»), nyoppstått falltendens, mobilitetssvikt og dehydrering. Pasienter med slike kliniske kjennetegn har behov for diagnostisk ekspertise og teknologi slik at alvorlig sykdom ikke blir oversett.

To norske studier har vist at det er vanskelig i en akuttsituasjon å velge ut de pasientene som kan ha nytte av tilbud på henholdsvis kommunalt nivå (3) og i sykehus (8). Videre at det er en tendens til at både innleggende leger og leger i mottakelsen lettere vurderer sosiale årsaker som viktige grunner til innleggelse jo eldre en pasient er (3).

Eldre pasienter har ofte et komplekst symptombilde. Det er derfor viktig at det ved iverksettelsen av samhandlingsreformen blir lagt til rette for at tiltakene er basert på dokumentert kunnskap. Lillebø og medarbeideres kasuistikk illustrerer behovet for betydelig kompetanseoppbygging både i primær- og spesialisthelsetjenesten når det gjelder behandling og oppfølging av sykdommer hos eldre, spesielt gjelder det demens og delirium. Det er ikke usannsynlig at innleggelsesterskelen for en del eldre pasienter er for høy. Det kan være at den sterke vektleggingen av å unngå innleggelser bør erstattes med tydelige kriterier for hvilke pasienter som alltid skal innlegges i sykehus, samtidig som man utvikler faglig fullverdige etterbehandlings- og rehabiliteringstilbud på kommunalt nivå $(6,9)$. Nye behandlingsalternativer både i og utenfor sykehus må alltid følges opp med gode, etterprøvbare studier på tvers av behandlingsnivåer. Bare slik kan tilbudet videreutvikles til beste både for pasientene og for samfunnet.

\section{Helge Garåsen}

helge.garasen@ntnu.no

Helge Garåsen (f. 1952) er spesialist i samfunnsmedisin. Han er kommunaldirektør for Helse og velferd i Trondheim kommune og førsteamanuensis ved Instituttgruppe for epidemiologi og helsetjenesteforskning, Institutt for samfunnsmedisin, Norges teknisk-naturvitenskapelige universitet.

Ingen oppgitte interessekonflikter.

\section{Litteratur}

1. Sosial- og helsedirektoratet. Legetjenester til personer med kommunale omsorgstjenester utenfor institusjon. Rapport IS 1420. Oslo: Sosial- og helsedirektoratet, 2006

2. Lillebø ML, Velle HO, Wyller TB. 77 år gammel kvinne innlagt av sosiale årsaker Tidsskr Nor Legeforen 2012; 132: 426-8.

3. Eikeland G, Garåsen H, Jacobsen G. Finnes det alternativer til øyeblikkelig hjelpinnleggelser? Tidsskr Nor Lægeforen 2005; 125: 2355-57.

4. Vist GE, Holte HH, Forsetlund $L$ et al. Alternativer til sykehusinnleggelse for eldre og personer med kronisk sykdom. Del 1: En oversikt over systematisk oppsummert forskning. Notat. Oslo: Nasjonalt kunnskapssenter for helsetjenesten. 2010.

5. Aaraas I. Sykestuer i Finnmark. En studie av bruk og nytteverdi. ISM skriftserie $\mathrm{nr}$ 45B. Doktoravhandling. Troms $\varnothing$ : Institutt for samfunnsmedisin, Universitetssykehuset Nord-Norge, 1998

6. Garåsen H, Windspoll R, Johnsen R. Intermediate care at a community hospital as an alternative to prolonged general hospital care for elderly patients: a randomised controlled trial. BMC Public Health 2007; 7: 68.

7. Sørbye LW, Grue EV, Vetvik E. Kunnskap om svikt i tjenester til skrøpelige eldre. Rapport 2009/5. Oslo: Diakonhjemmet Høgskole, 2009.

8. Eriksen BO. The potential for reducing inappropriate hospital admissions: a study of health benefits and costs in a department of internal medicine. Doktoravhandling. Tromsø: Institutt for samfunnsmedisin, Universitetssykehuset Nord-Norge, 1999

9. Indredavik B, Fjærtoft $H$, Ekeberg $G$ et al. Benefit of an extended stroke unit service with early supported discharge: a randomized controlled trial. Stroke 2000; 31: $2989-94$ 